\title{
Pembelajaran Saintifik pada Anak Usia Dini dalam Pengembangan Kreativitas di Taman Kanak-Kanak
}

\author{
Sri Marwiyati ${ }^{\otimes_{1}}$, Istiningsih $^{2}$ \\ Pendidikan Islam Anak Usia Dini, Institut Agama Islam Negeri Salatiga ${ }^{1}$ \\ Pendidikan Guru Madrasah Ibtidaiyah, Universitas Islam Negeri Sunan Kalijaga \\ Yogyakarta ${ }^{2}$ \\ DOI: $\underline{10.31004 / o b s e s i . v 5 i 1.508}$
}

\begin{abstract}
Abstrak
Penelitian ini bertujuan untuk mengetahui penerapan pembelajaran saintifik anak usia dini di TK Negeri Pembina Salatiga. Metode penelitian yang digunakan adalah kualitatif deskriptif. Data yang diperoleh dari hasil wawancara, observasi dan dokumentasi yang bersumber dari TK Negeri Pembina Kota Salatiga. Data yang terkumpul ditindaklanjuti dengan reduksi data, display data dan menarik kesimpulan. Kurikulum 2013 merupakan kurikulum yang menekankan pada pendekatan saintifik, meskipun dalam pelaksanaannya masih ada guru belum sepenuhnya menerapkannya. TK Negeri Pembina merupakan sekolah PAUD pertama di Salatiga yang menerapkan pembelajaran dengan pendekatan saintifik. Hasil penelitian menunjukkan pelaksanaan pembelajaran saintifik belum terlaksana dengan maksimal, guru kesulitan dalam mengontrol dan memberikan penilaian di setiap aktivitas anak dikarenakan rasio guru terhadap murid di TK Negeri Pembina kelompok B melebihi rasio ideal yaitu lebih dari 1:15. Pembelajaran saintifik mampu merangsang kreativitas anak karena anak lebih mandiri, percaya diri, berani berpendapat, dan rasa ingin tahu yeng tinggi sebagai ciri kreatif.
\end{abstract}

Kata Kunci: Pembelajaran Saintifik, keterampilan ilmiah guru, Kreativitas

\begin{abstract}
This study aims to determine the implementation of early childhood scientific learning in TK Negeri Pembina Salatiga. The research method used is descriptive qualitative. Data obtained from the results of interviews, observations and documentation taken from TK Negeri Pembina Salatiga City. The collected data is followed up with data reduction, data display and conclusions. The 2013 curriculum is a curriculum that emphasizes a scientific approach, although in practice there are still teachers who have not fully implemented it. TK Negeri Pembina is the first PAUD in Salatiga that implements learning with a scientific approach. The results showed the implementation of scientific learning had not been carried out to the maximum target, the teacher had difficulty in controlling and giving an assessment in each child's activities because the ratio of teachers to students in TK Negeri Pembina group B exceeded the ideal ratio of more than 1:15. Scientific learning is able to stimulate children's creativity because children are more independent, confident, courageous in their opinions, and curiosity is high as a creative trait.
\end{abstract}

Keywords: Scientific Learning, teacher scientific skills, creativity

Copyright (c) 2020 Sri Marwiyati, Istiningsih

$\triangle$ Corresponding author:

Email Address : marwi.piaud@iainsalatiga.ac.id (Salatiga, Indonesia)

Received 20 April 2020, Accepted 8 May 2020, Published 13 May 2020 


\section{PENDAHULUAN}

Menurut Gadner (2011:29), "people are born with certain amount of intelligences", setiap anak memiliki lebih dari satu potensi kecerdasan yang bisa berkembang, perkembangan tersebut antara satu anak dengan anak lain tidak sama. Anak memerlukan pembinaan dan stimulasi yang tepat untuk mengasah potensi dan kemampuannya secara optimal. Kemampuan anak yang tidak dikembangkan, maka anak tersebut akan kehilangan periode emas dalam hidupnya (Sumiyati, 2014:12). Anak yang terbiasa diberikan stimulasi positif sejak usia dini akan menjadikan anak tersebut mempunyai potensi unggul di dalam dirinya, sehingga diperlukan program pendidikan yang mampu membuka dan merangsang potensi diri anak (Aryanti, 2016:57).

Pendidikan bagi anak usia dini sebagai pondasi awal pendidikan harus dilaksanakan semaksimal mungkin, orang tua adalah pendidik pertama dan utama dalam memberikan pendidikan dan pengajaran bagi anak. Ketika anak masuk dalam lingkungan sekolah gurulah yang membantu peran dari orang tua. Guru memiliki peran dalam memberikan fasilitas bagi anak agar mampu meningkatkan kemampuan yang telah dimiliki. Guru memiliki peran merancang pembelajaran, memberikan motivasi pada anak untuk selalu meningkatkan kemampuannya dan melaksanakan pembelajaran yang menyenangkan, berpusat pada anak, memberikan keleluasaan kreativitas bagi anak serta meningkatkan aspek perkembangan agama dan moral, fisik-motorik, kognitif, bahasa, sosial emosional, dan seni (Menteri Pendidikan Dan Kebudayaan Republik Indonesia, 2014)

Kurikulum 2013 merupakan kurikulum yang menekankan pembelajarannya dengan pendekatan saintifik dan penilaian autentik (Menteri Pendidikan Dan Kebudayaan Republik Indonesia, 2014). Pendekatan saintifik yaitu pembelajaran yang berbasis fakta/kongkrit yang dapat dijelaskan dengan logika berpikir, menginspirasi anak untuk dapat berpikir kritis, mampu menganalisis dan tepat dalam mengidentifikasi, memahami dan memecahkan masalah (Rusman, 2015:231). Menurut kemendikbud, pendekatan saintifik merupakan pendekatan dalam membangun cara berpikir anak agar anak memiliki kemampuan menalar yang diperoleh melalui proses mengamati, menanya, mengumpulkan informasi, menalar dan mengkomunikasikan. Penilaian autentik adalah kegiatan menilai dengan menekankan apa yang seharusnya dinilai, baik proses pembelajaran dan hasil belajar dengan berbagai intrumen penilaian yang disesuaikan dengan kompetensi yang ada dalam Standar Kompetensi (SK) atau Kompetensi Inti (KI) dan Kompetensi Dasar (KD) (Kunandar, 2013:35). Proses pembelajaran pada kurikulum 2013 mulai dari jenjang PAUD sampai dengan Pendidikan Menengah dilaksanakan dengan pendekatan saintifik.

Pembelajaran dengan pendekatan saintifik mampu memberikan kontribusi yang positif dalam meningkatkan kemampuan berpikir kritis pada anak, mengembangkan karakter dan kecerdasan anak sehingga anak mampu memecahkan masalah sederhana (Yunita, Meilanie, \& Fahrurrozi, 2019). Kebiasaan yang positif ini jika sering diterapkan dan dilakukan oleh anak, maka ke depannya anak-anak akan menjadi anak yang handal dan siap menghadapi perubahan zaman. Pembelajaran saintifik tidak hanya memandang hasil belajar sebagai muara akhir, namun proses pembelajaran dipandang sangat penting. Pembelajaran saintifik memiliki karakteristik sebagai berikut: a) Berpusat pada anak, dengan mempertimbangkan potensi, bakat, minat, perkembangan, dan kebutuhan anak; b) Melibatkan keterampilan proses sains dalam mengkonstruksi konsep, hukum atau prinsip; c) Melibatkan proses-proses kognitif yang potensial dalam merangsang keterampilan berpikir tingkat tinggi siswa; d) Dapat mengembangkan karakter anak, pemberian rangsangan pembelajaran diarahkan untuk mengembangkan nilai-nilai karakter (Daryanto, 2015:53).

TK Negeri Pembina merupakan satu-satunya TK berstatus negeri yang berada di Kota salatiga. Pada tahun ajaran 2015/2016 di tuntut oleh Dinas Pendidikan Kota untuk menerapkan kurikulum 2013, dimana lembaga pendidikan PAUD yang lain belum menerapkan, sehingga TK Pembina menjadi percontohan penerapan kurikulum 2013 pada 
tingkat TK di wilayah kota Salatiga, sehingga penulis tertarik untuk melakukan penelitian di TK tersebut. Tujuan dari penelitian ini adalah untuk mendeskripsikan tentang pembelajaran saintifik di TK Negeri Pembina Kota Salatiga dan upaya-upaya yang dilakukan oleh guru dalam dalam mengembangkan kreativitas anak usia dini.

Penelitian tentang Pembelajaran saintifik telah beberapa kali dilakukan, hasil penelitian yang ditulis Istiningsih (2014) dalam IOSR Journal of ResearchEMethod in Education (IOSR-JRME) "Relationship Between Religious Consciousnesses With Scientific Learning (Case Study In Islamic Basic School In Malaysia And Indonesia)", penelitian ini untuk mengetahui hubungan kesadaran beragama dengan scientific learning, kesadaran beragama siswa dapat dilihat dari perilaku mereka. Dari penelitian ini didapat hasil bahwa sekolah yang memberikan dorongan dan stimulasi yang lebih terhadap perilaku siswa akan menjadikan siswa memiliki perilaku yang baik. Kesadaran beragama memiliki kaitan erat dengan pembelajaran ilmiah, kesadaran beragama dapat menjadi program sekolah ketika akan meningkatkan pembelajaran ilmiah siswa

Penelitian selanjutnya adalah penelitian oleh Dyers, J.H dalam Jurnal Pendidikan Islam yang dikutip oleh Imam Machali, pembelajaran berbasis kreativitas memberikan hasil peningkatan sampai $200 \%$ dibandingkan dengan pembelajaran berbasis kecerdasan yang hanya mengalami kenaikan $50 \%$. Pendekatam saintifik adalah pembelajaran yang bertujuan mengaktifkan dan menumbuhkan kreativitas siswa, sehingga untuk membentuk kreativitas peserta didik, pembelajaran dengan pendekatam saintifik diyakini dapat membantu meningkatkannya (Machali, 2014:89).

Penelitian Yusri (2015), "Keterkaitan Scientific learning dengan kemampuan berpikir kritis (Kajian Proses Pembelajaran di Sekolah Dasar Budi Mulia Dua Sedayu Bantul). Keterkaitan scientific learning skill siswa dan berpikir kritis adalah pembelajaran yang terdiri dari mengamati, mengklasifikasi, mengkomunikasikan secara bersama-sama berpengaruh terhadap kemampuan berpikir siswa sebesar $68 \%$ dan sisanya 32\% dipengaruhi faktor lain diluar scientific learning skill anak.

Penelitian ini berbeda dengan penelitian sebelumnya, meskipun ada beberapa yang membahas tentang pembelajaran saintifik tapi belum sepenuhnya fokus pada pembelajaran pada anak usia dini yang melibatkan keterampilan saintifik guru serta pengembangan kreativitas anak usia dini, untuk itu perlu dilakukan penelitian bagaimana penerapan pembelajaran saintifik pada sekolah PAUD percontohan yang menerapkan pembelajaran saintifik dan menganalisa keterampilan saintifik yang telah dilakukan oleh guru pendidikan anak usia dini dalam upaya mengembangkan kreativitas anak.

\section{METODOLOGI}

Penelitian ini merupakan penelitian kualitatif yaitu penelitian yang bersifat deskriptif yang menggambarkan secara sistematis mengenai hal-hal yang ditemukan di lokasi penelitian yang bersifat verbal. Penelitian ini dilaksanakan di TK Negeri Pembina Kota Salatiga yang berlokasi di JL. Ngadisari II Tegalrejo Kecamatan Argomulyo kota Salatiga Provinsi Jawa Tengah. Penelitian ini dilaksanakan pada bulan April - Mei 2017.

Subjek penelitian yang peneliti pilih yaitu kepala sekolah sebagai pemangku kebijakan, guru kelas dan siswa yang terlibat dalam proses pembelajaran serta wali murid yang mengetahui perkembangan anak selama di rumah. Siswa yang terlibat dalam penelitian ini adalah kelompok B yang berjumlah 28 anak. Metode pengumpulan data dalam penelitian ini menggunakan observasi langsung, wawancara dan dokumentasi. Observasi langsung yaitu peneliti terlibat dalam aktivitas kegiatan pembelajaran di TK Negeri Pembina dari kegiatan awal sampai anak pulang. Wawancara yaitu kontak langsung secara tatap muka dan lisan dengan sumber data penelitian, yaitu dengan kepala sekolah, guru dan wali murid. Dokumentasi yaitu dokemunen berupa foto kegiatan dan data-data pendukung yang lain.

Data yang telah terkumpul kemudian dianalisis menggunakan model Miles \& Huberman yang meliputi reduksi data, mendisplay data dan menarik kesimpulan (Miles \& 
Huberman, 2012:16). Kemudian dilakukan uji keabsahan data untuk mengetahui data yang sebenar-benarnya, uji keabsahan data dalam penelitian ini menggunakan teknik triangulasi sumber yaitu membandingkan dan mengecek kebenaran suatu data atau informasi yang diperoleh, yaitu dengan membandingkan satu data dengan sumber yang lain seperti perbandingan hasil pengamatan dengan hasil wawancara atau dokumentasi. Dalam penelitian ini peneliti membandingkan hasil wawancara guru terkait dengan pembelajaran saintifik dalam pengembangan kreativitas anak dengan hasil pengamatan peneliti dan juga hasil wawancara dengan walimurid serta dokumen hasil belajar anak. Peneliti juga membandingkan hasil pengamatan peneliti tentang keterampilan guru dalam mengajar melalui pendekatan saintifik dengan hasil wawancara dari guru juga kepala sekolah, sehingga didapatkan data yang sebenar-benarnya. Berikut alur kegiatan penelitian dapat digambarkan sebagai berikut:

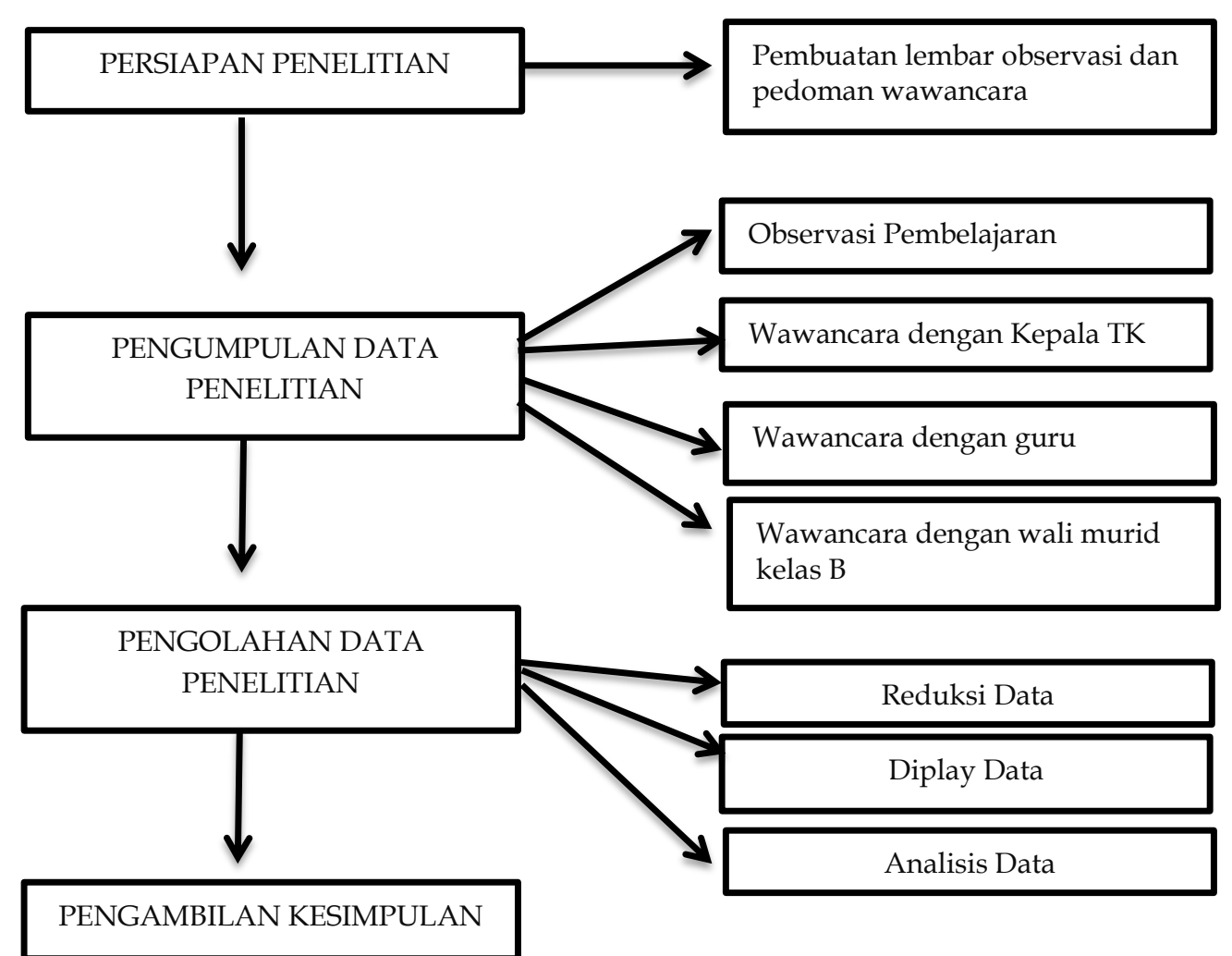

Gambar 1. Alur Penelitian

\section{HASIL DAN PEMBAHASAN}

\section{Pembelajaran saintifik pada Anak Usia Dini di TK Negeri Pembina Kota Salatiga}

Kegiatan pembelajaran di TK Negeri Pembina dimulai dari kegiatan pembuka, yaitu anak-anak berbaris di depan kelas masing-masing untuk melakukan gerakan sederhana melalui nyanyian, kemudian masuk ke kelas dengan bersalaman dengan guru kelas. Kemudian anak duduk dikarpet dengan melingkar kadang juga membanjar. Berdasarkan observasi, kegiatan pembelajaran yang dilakukan oleh guru dalam pendahuluan adalah mengkondisikan suasana belajar yang menyenangkan dengan memberikan nyayian dan motivasi agar anak semangat dan ceria.

Berdasarkan observasi, wawancara dan dokumentasi diperoleh data bahwa pembelajaran yang dilakukan oleh guru disini sudah mulai menunjukkan kegiatan $5 \mathrm{M}$ yaitu mengamati, menanya, mengumpulkan informasi, menalar dan mengkomunikasikan. Berikut SOP kegiatan inti pembelajaran sebagai dasar pelaksanaan pembelajaran di TK Negeri Pembina: 
Tabel 1. SOP Kegiatan Inti TK Negeri Pembina

\begin{tabular}{|c|c|}
\hline $\begin{array}{l}\text { Prosedur } \\
\text { Kerja }\end{array}$ & $\begin{array}{l}\text { 1. Melakukan (pengamatan) dan membuat catatan perkembangan anak. } \\
\text { 2. Memberikan penguatan dengan menggunakan kalimat bertanya yang terbuka } \\
\text { secara tepat. } \\
\text { 3. Penguatan yang diberikan harus sesuai dengan perkembangan anak } \\
\text { 4. Dorong anak untuk bermain/ melakukan kegiatan dalam kelompok kecil selain } \\
\text { bermain secara mandiri. } \\
\text { 5. Anak diberi kesempatan untuk membuat karya dengan idenya sendiri. } \\
\text { 6. Anak diberi kesempatan untuk mencoba alat dan bahan main dengan cara sendiri. } \\
\text { 7. Membangun kepercayaan diri anak dengan memberikan kesempatan untuk } \\
\text { mengemukakan gagasannya melalui alat dan bahan main yang digunakannya. }\end{array}$ \\
\hline
\end{tabular}

Selain SOP, pedoman pelaksanaan pembelajaran yang dipakai adalah RPPH yang dipersiapkan guru sehari sebelum pelaksanaan pembelajaran. Dalam RPPH guru mempersiapkan alat dan bahan yang akan dipakai dalam proses pengamatan, mengumpulkan informasi, mempersiapkan kegiatan untuk anak menalar, dan mengkomunikasikan. Adapun pelaksanaan pembelajaran saintifik di TK Negeri Pembina dengan 5M dapat diuraikan sebagai berikut:

\section{Mengamati}

Berdasarkan observasi yang dilakukan peneliti, kegiatan mengamati yang dilakukan siswa adalah mengamati gambar pada buku ensiklopedi yang dibawa oleh guru, mengamati mainan pesawat dan helikopter dan memegang mainan tersebut secara bergantian, menonton video pesawat landing dan take off yang ditanyangkan oleh guru. Dalam kegiatan mengamati guru memberikan kesempatan kepada anak untuk mengamati dengan melibatkan banyak indra, dengan mata anak melihat gambar pesawat, kapal, video dan yang dilihatkan oleh guru, sehingga siswa dapat melihat bentuk, warna, serta gerak suatu objek. Dengan pendengaran siswa bisa mendengarkan penjelasan guru dan suara pesawat dari video yang diputarkan oleh guru. Dengan perabaan mereka bisa memegang mainan pesawat untuk melihat dan memegang bagian-bagian pesawat dan menjalankan pesawat. Hasil observasi menunjukkan siswa mulai berpartisipasi aktif dalam pembelajaran dan menunjukkan semangat dan serius dalam belajarnya. Guru menggunakan media yang menarik, sehingga anak sangat antusias dan senang dalam kegiatan mengamati karena anak bisa memegangnya, menyentuhnya sehingga membantu daya imajinasi anak. Media merupakan sarana dalam menunjang pebelajaran sehingga meningkatkan perhatian anak serta menimbulkan motivasi belajar bagi anak (Maimunah, 2016). Kegiatan mengamati kecendurungn guru sebagai pusat pembelajaran masih ada anak masih mengikuti apa yang diperintahkan oleh guru dan belum berdasarkan keinginan anak.

\section{Menanya}

Kegiatan menanya dan bertanya antara guru dan anak adalah sebagai proses menggali pengetahuan baru. Guru dapat membantu anak untuk menyusun pertanyaan yang ingin mereka ketahui. Dalam proses pembelajaran fungsi bertanya adalah sebagai pendorong dan menginspirasi peserta didik untuk aktif belajar, serta mengembangkan pertanyaan dari dan untuk dirinya sendiri (Daryanto, 2015:64).

Dalam pembelajaran guru memberikan pertanyaan-pertanyaan terkait tema pembelajaran, guru memberikan penjelasan sederhana, dan memberikan beberapa pertanyaan kepada anak, dalam bertanya yang dominan bertanya adalah guru, sedangkan dari anak hanya beberapa saja yang bertanya. Ketika anak menyampaikan pertanyaan baik terkait tema maupun tidak, guru memberikan tanggapan apa yang menjadi pertanyaan anak. Dari observasi peneliti dan wawancara dengan guru setiap kegiatan pembelajaran guru TK Negeri Pembina sudah membuka kesempatan kepada anak-anak untuk bertanya mengenai apa yang sudah disimak dan dilihat. Guru membimbing siswa untuk mengajukan 
pertanyaan dan guru memberikan pertanyaan terbuka untuk membuka seluas-luasnya pengetahuan anak. Tapi anak-anak belum semua bisa menyampaikan pertanyaan tentang apa yang sudah diketahuinya, kadang anak sering bertanya tentang suatu hal yang lain di luar pembelajaran, anak masih malu dalam bertanya sehingga anak-anak masih perlu bimbingan dalam bertanya

Sifat dasar anak adalah bertanya, sebagai guru atau orang tua jangan bosan-bosan menjawab pertanyaan anak, meskipun menanyakan hal-hal yang diluar pelajaran, hal-hal yang abstrak atau menanyakan hal yang sama secara berulang-ulang. Perilaku mengajukan pertanyaan adalah mencerminkan logika proses berpikir anak, bertanya dapat membangkitkan rasa ingin tahu anak serta memicu kreativitas anak (Hariyadi, 2014).

\section{Mengumpulkan informasi}

Mengumpulkan informasi merupakan tindak lanjut dari proses bertanya. Proses pengumpulan informasi dilakukan dengan melibatkan seluruh sumber belajar yang ada di lingkungan bisa didapat dari buku, internet, orang tua, mengamati objek/kejadian, akativitas wawancara dengan narasumber, kunjungan tempat dan sebagainya, sehingga guru bukan sumber informasi utama dalam belajar (Kemendikbud, 2015).

Hasil penelitian menunjukkan, kegiatan mengumpulkan informasi di TK Negeri Pembina dilakukan dengan meminta anak mengamati objek yang yang dipelajari dengan cara melihat media atau peraga yang dibawa oleh guru yaitu buku ensiklopedia, video, mainan anak, menirukan gerakan dan bunyi yang dikeluarkan. Dalam mengumpulkan informasi anak-anak mendapatkan pengalaman dan pengetahuan dari berbagai sumber belajar Sumber belajar masih dari lingkup lingkungan sekolah dalam hal ini dari guru, belum dari luar sekolah seperti kunjungan tempat atau wawancara dengan narasumber lain.

Dalam mengumpulkan informasi, informasi masih banyak yang bersumber dari guru, guru membawa buku, video, gambar dan alat peraga, kemudian anak memperhatikan, mendengar dan melihat sumber belajar yang dibawa oleh guru untuk mendapatkan informasi. Informasi yang bersumber dari anak belum dimunculkan, guru belum memberikan kesempatan kepada anak untuk berbagi pengalaman tentang hal yang dipelajari hari ini, melalui cerita dan lain-lain. Dampak yang muncul dengan pembiasaan anak mengumpulkan informasi dari berbagai sumber belajar dan berbagia cara adalah sikap teliti, jujur, sopan, menghargai pendapat orang lain, kemampuan berkomunikasi (Kemendikbud, 2013).

Bentuk dukungan yang diberikan kepada anak dalam mengumpulkan informasi diantaranya: guru memberikan waktu cukup dalam kegiatan pengamatan, bereksplorasi dan lain-lain agar anak mendapatkan pengetahuan dan informasi yang detail dan lebih rinci. Guru memfasilitasi kegiatan pengamatan, eksperimen dan lain-lain pada anak, ketika anak bertanya guru berusaha menjawab sebagai bentuk perhatian guru kepada anak sehingga anak merasa percaya diri.

\section{Menalar}

Kegiatan menalar atau mengasosiasi merupakan proses dalam anak menghubungkan pengalaman baru dengan pengetahuan lama. Dalam Pedoman Pengelolaan Pembelajaran PAUD, tahap menalar dilakukan melalui tiga kegiatan utama, yaitu: membandingkan (comparing), mengelompokkan (classifiying), pengukuran (measuring using tools) (Kemendikbud, 2015:29).

Dari hasil observasi kegiatan menalar dilakukan dengan meminta anak melakukan perbandingan, pengukuran, dan mengelompokkan. Kegiatan membandingkan dapat dilihat ketika guru meminta membandingkan kecepatan antar kendaraan bus, kereta, pesawat terbang. Ada anak yang bercerita ketika naik mobil pernah dan melihat pesawat terbang dengan cepat. Kemudian guru memeragakan jalannya mobil dan pesawat secara bersamaan, anak diminta menjawab lebih cepat pesawat atau mobil, kemudian guru bersama anak-anak 
membuat kesimpulan kalau pesawat lebih cepat dari mobil. Pada kegiatan mengukur tampak pada kegiatan pembuatan hasil karya yang mereka buat seperti membuat pesawat mainan dari botol bekas. Sebelum membuat anak diminta guru membandingkan botol yang besar dan kecil, untuk botol yang besar menggunakan sayap pesawat yang besar, untuk botol yang kecil menggunakan sayap pesawat yang kecil. Dengan demikian anak dapat mengembangkan keterampilan dalam pengukuran. Pada kegiatan mengklasifikasikan, guru meminta anak mengelompokkan kendaraan darat, laut dan udara. Siswa diminta menyebutkan macam-macam kendaraan udara, kendaraan laut, kendaraan darat. Anakanak menyebutkannya satu demi satu secara bergantian atau bergilir. Kemudian guru meminta kepada anak untuk meletakkan kendaraan darat pada jalan darat, meletakkan kendaraan air/laut pada air dan kendaraan yang bisa terbang di udara.

Dalam kegiatan menalar anak masih dibimbing oleh guru, seperti dalam hal menghubungkan informasi satu dengan informasi lain. Kegiatan menalar merupakan hal yang penting dan harus dimiliki peserta didik, karena melalui kegiatan ini peserta didik akan dapat mengolah informasi dengan mengaitkan informasi satu dengan lainnya yang kemudian perlu menarik kesimpulan (Sani, 2015:66).

\section{Mengkomunikasikan}

Keterampilan mengkomunikasikan dalam kegiatan pembelajaran adalah menyampaikan hasil pengamatan, kesimpulan berdasarkan hasil analisis secara lisan, tertulis, atau media lainnya, kemudian dikembangkan atau dituangkan ke dalam berbagai hasil karya (Kemendikbud, 2013). Mengkomunikasikan merupakan proses penguatan pengetahuan baru yang didapat oleh anak. Mengkomunikasikan dilakukan dengan verbal, gerakan, hasil karya. Pada pembelajaran saintifik guru memberikan kesempatan kepada anak untuk mengkomunikasikan apa yang telah mereka pelajari. Hasil tersebut dinilai oleh guru sebagai hasil belajar anak.

Berdasarkan hasil observasi dan dokumentasi pembelajaran saintifik anak usia dini TK Negeri Pembina Kota Salatiga keterampilan mengkomunikasikan dilaksanakan dengan berbagai cara. Anak mendapat kesempatan untuk berbagi pengalaman berdasarkan informasi yang didapatkan hari ini melalui cerita di depan teman-teman, menirukan gerakan, menirukan bunyi, hasil karya yang dibuat anak serta dengan cara anak bermain dan bereksplorasi.

Setiap hasil karya anak, guru memberikan pujian dan penghargaan, dengan harapan rasa percaya diri anak akan lebih meningkat, kreativitas anak juga semakin berkembang dan anak akan semakin tertantang untuk meningkatkan bakat dan kemampuannya. Dalam mengkomunikasikan anak-anak masih membutuhkan pendampingan dan bimbingan. Anak belum mampu dilepaskan begitu saja dalam membuat hasil karya. Dukungan yang baik dan tepat dari guru akan menguatkan pemahaman anak terhadap konsep atau pengetahuannya.

Melalui mengkomunikasikan, ketelitian dan menghargai karya teman yang lain juga tumbuh. Selain itu dapat anak dapat mengungkapkan pendapat sehingga kemampuan berbahasa dapat berkembang dengan baik. Hal ini senada dengan M. Hosnan bahwa dalam mengkomunikasikan dapat mengembangkan sikap jujur, teliti, toleransi, kemampuan berpikir sistematis, mengungkapkan pendapat secara singkat dan jelas, dan mengembangkan kemampuan anak berbahasa baik dan benar (Hosnan, 2014:76).

Berdasarkan hasil observasi, dokumenasi dan wawancara, TK Negeri Pembina Salatiga sudah berusaha melaksanakan pembelajaran dengan pedekatan saintifik seperti mengamati, menanya, mengumpulkan informasi, menalar, dan mengkomunikasikan. Akan tetapi dalam pelaksanaan pembelajarannya peran guru masih sangat dominan, anak-anak mendapatkan informasi/pengetahuan dari apa yang disampaikan oleh guru. Anak belum sepenuhnya mengembangkan kemampuan atau pengalaman yang dimiliki seperti, saling bertukar informasi tentang materi yang dibahas, karena anak lebih sering mendengarkan materi dari guru. Kemampuan dalam bertanya pada anak juga belum berkembang, 
sehingga guru lebih dominan yang memberikan pertanyaan kepada anak. Guru kesulitan dalam membimbing dan mengontrol siswa, dengan jumlah siswa 28 tanpa ada guru pendamping, guru kesulitan ketika semua anak harus dibimbing, dan di awasi secara penuh mulai dari kegiatan mengamati sampai mengkomunikasikan.

\section{Keterampilan Saintifik Guru dalam Melaksanakan Pembelajaran Saintifik pada Anak Usia Dini di TK Negeri Pembina Kota Salatiga}

TK Negeri Pembina Salatiga tahun ajaran 2015/2016 mulai menerapkan kurikulum 2013 dengan pendekatan saintifik, sebelumnya kurikulum yang digunakan adalah KTSP. Penerapan pembelajaran dengan pendekatan saintifik guru tidak lagi menjadi pusat belajar anak, tetapi anak menjadi pembelajar aktif dan kreatif dalam mencari sumber belajar, anak tidak hanya mengikuti perintah guru tetapi melakukan atas dasar idenya, sehingga tercipta pembelajaran yang menyenangkan (Angkur, 2019). Guru berperan memfasilitasi belajar anak mengolah proses pembelajaran, memacu semangat belajar anak dan lain-lain..

Dari hasil wawancara dengan kepala sekolah TK Negeri Pembina, bahwa tiap awal tahun ajaran guru dan kepala sekolah secara bersama-sama mempersiapkan perangkat pembelajaran sebagai perencanaan pembelajaran dalam satu tahun ajaran kedepan. Guru harus mampu dan siap merancang kegiatan pembelajaran yang dapat mendukung proses pembelajaran, rancangan tersebut setidak-tidaknya meliputi hal-hal sebagai berikut: memilih dan menentukan bahan ajar, merumuskan tujuan penyajian bahan pelajaran, memilih metode penyajian bahan pelajaran yang tepat, menyelenggarakan kegiatan evaluasi prestasi belajar (Uno, 2009:23).

Berdasarkan data dokumentasi dan wawancara, dalam mempersiapkan objek belajar, guru TK Negeri Pembina mengelola kegiatan akademik dimulai dari pembuatan perangkat pembelajaran seperti pembuatan silabus, jadwal pelajaran dan perangkat lain yang terkait dengan kegiatan belajar mengajar seperti Program Tahunan (Prota), Program Semester (Promes), RPPM (Rencana Pelaksanaan Pembelajaran Mingguan), RPPH (Rencana Pelaksanaan Pembelajaran Harian), rencana penilaian dan lain-lain. Prota, Promes, dan RPPM dibuat guru dan kepala sekolah sebelum awal tahun ajaran, RPPH dibuat sehari sebelum pembelajaran terlihat dari penanggalan $\mathrm{RPPH}$ sehari sebelum pelaksanaan pembelajaran yang mengacu pada RPPM. Sehari sebelum pembelajaran, guru mempersiapkan alat dan bahan yang diperlukan dengan tujuan untuk mempermudah pembelajaran, guru juga mempersiapkan kegiatan yang akan dilakukan anak untuk meningkatkan keterampilan anak dalam mengawasi, bertanya, mengumpulkan informasi, menalar dan mengkomunikasikan, hal ini tampak dalam dokumen RPPH yang dibuat oleh guru.

Selama proses pelaksanaan pembelajaran, guru melakukan berbagai kegiatan seperti membantu anak yang kesulitan dalam menyelesaikan tugas membuat hasil karya, menegur anak yang mengganggu temannya, mengawasi siswa dalam proses mengamati jika ada anak yang kurang konsentrasi guru mengingatkan anak untuk memperhatikan, guru merespon hal-hal yang menjadi pertanyaan anak baik pertanyaan yang berhubungan dengan tema atau keluar dari tema pembelajaran, memantau anak yang melihat buku, anak bermain, membantu anak yang masih memerlukan bimbingan dan arahan karena perkembangan tiap anak berbeda-beda, dan melihat anak yang sudah mampu menyampaikan ide-ide dan pendapatnya melalui tulisan, lisan dan hasil karya.

Ketika guru melihat ada anak yang mulai tidak semangat belajar, seperti anak sering bilang "tidak bisa, tidak mau, capek", guru TK Negeri Pembina selalu memberikan motivasi kepada anak agar semangat lagi dalam belajar. Dengan memberikan pendampingan dan memotivasi dengan memberikan kata-kata positif seperti, "kamu pasti bisa, kamu keren, kamu hebat, kamu pintar" agar anak bangkit lagi. Selain membangkitkan semangat anak yang sudah menurun, kata positif juga diberikan kepada anak untuk setiap hasil karya anak, untuk anak yang berani bertanya dan berpendapat, dengan cara memberikan acungan 
jempol sambil memberikan kalimat positif kepada anak. Kalimat positif dari guru adalah sebagai bentuk motivasi yang diberikan yang diharapkan jiwa positif anak berkembang.

Selama proses pembelajaran, guru memperhatikan interaksi antar anak dengan teman, lingkungan, bekerjasama, kemandirian dan lain-lain. Ketika tiba waktu untuk istirahat, guru meminta anak-anak untuk bermain diluar kelas, guru di TK ini tidak duduk diam di dalam kelas tetapi semua guru ikut keluar kelas untuk mengontrol kegiatan bermain anak dan untuk mengantisipasi kejadian yang tidak diinginkan pada anak. Untuk membangun komunikasi dengan orang tua, guru membuat grup diskusi dengan wali murid dengan via WhatsApp, dan juga membuat buku penghubung yang diberikan setiap seminggu sekali. Dengan demikian dapat membantu guru dalam pemantauan perkembangan anak. Guru memantau anak mulai dari datang sampai anak pulang. Berdasarkan hasil observasi peneliti, tidak semua anak dapat terkontrol oleh guru, karena terlalu banyak anak yang diawasi dan tidak ada guru pendamping dalam kelas, guru kurang maksimal sehingga anak-anak ada yang tidak terawasi bahkan terabaikan.

Seorang guru harus memberikan kemudahan dalam dalam belajar anak, juga mampu menciptakan kegiatan belajar yang nyaman dan menyenangkan sehingga anak tidak ada tekanan dalam belajar. Seorang guru harus bersikap baik, memahami terhadap peserta didik dan mampu menyikapi perbedaan individual peserta didik (Mulyasa, 2013:41). Guru TK Negeri Pembina mempersiapkan media, materi dan alat peraga yang akan digunakan dalam proses pembelajaran setiap hari sehingga memberikan kemudahan anak dalam belajar karena anak belajar secara kongkrit. Guru mengajak anak untuk mengamati gambar macam-macam kendaraan dari buku esiklopedi anak, video berbagai macam kendaraan udara dan laut, anak memegang berbagai macam mainan kendaraan dan lain-lain. Untuk tema yang lain ada kalanya siswa diajak jalan- jalan keluar kelas untuk mengamati sekitar sekolah seperti mengenal tanaman, mengenal bagian rumah, sekolah dan lain-lain. Dalam membuat hasil karya untuk anak guru mempersiapkan bahan yang akan dibuat oleh anak sehingga mempermudah anak dalam membuat hasil karya.

Dari hasil wawancara dengan guru, seteleh kegiatan pembelajaran selesai guru melakukan penilaian terhadap hasil karya yang dibuat oleh anak, pada tahun ajaran awal guru melakukan kegiatan penilaian ketika proses pembelajaran berlangsung, guru membiarkan anak melakukan hal-hal yang betul-betul diinginkan anak dan mengkomunikasikan hasil karyanya bebas sesuai dengan kemampuan dan keinginan anak dan guru hanya mengawasi dan menilai perkembangan anak. Akan tetapi banyak anak yang kemandiriannya belum berkembang, percaya diri anak juga belum muncul sehingga guru melakukan bimbingan dan mendampingi anak dalam belajar, sehingga pencatatan penilaian ketika proses pembelajaran belum bisa terlaksana.

Proses penilaian yang dilakukan oleh guru TK Negeri Pembina belum bisa dilakukan secara maksimal, penilaian yang dilakukan saat anak-anak bermain dan saat anak melakukan suatu kegiatan tidak bisa terlaksana dengan baik, karena guru harus membimbing anak-anak dan mendampingi anak yang masih mengalami kesulitan belajar. Guru melakukan penilaian terhadap anak ketika kegiatan pembelajaran sudah selesai atau ketika anak sudah pulang. Dalam melakukan penilaian guru mengingat-ingat terhadap aktivitas anak satu persatu sehingga hasil dari penilaian belum semuanya autentik. Penilaian autentik merupakan penilaian yang berorientasi pada kegiatan belajar yang berkesinambungan dan hasil belajar yang mencerminkan kemampuan anak saat melaksanakan kegiatan belajar (Menteri Pendidikan Dan kebudayaan RI, 2014). Kemampuan mengingat seseorang terbatas apalagi untuk mengingat aktivitas anak yang banyak dan beragam sehingga penilaian yang dilakukan guru disini belum sepenuhnya berdasarkan catatan asli saat proses pembelajaran berlangsung. Penilaian harus dilakukan secara alami, yaitu ketika anak bermain, menggambar, membuat karya dan lainnya (Mundia Sari \& Setiawan, 2020). Dalam melakukan penilaian guru tidak membandingkan satu anak dengan anak lain, semua anak dicatat dan diketahui perkembangannya. Dalam melakukan 
penilaiaan guru berusaha mencatat perkembangan semua anak sehingga dapat diketahui kelebihan dan kekurangan atau kesulitan belajar anak. Dengan mengetahui kelebihan atau bakat anak, sehingga guru dapat membantu mengembangkan kemampuannya.

Menurut Istiningsih (2014), indikator keterampilan saintifik guru adalah kemampuan guru dalam mengelola proses pembelajaran, melakukan pengawasan, memfasilitasi permasalahan siswa dan kompetensi guru dalam melakukan evaluasi. Keterampilan belajar saintifik siswa yaitu keterampilan siswa dalam aktivitas mengamati, menanya, mengumpulkan informasi, menalar dan mengkomunikasikan. Dari kegiatan pembelajaran di TK Negeri Pembina dapat terlihat bahwa keterampilan saintifik sebagai organisator, monitor, fasilitator dan evaluator sudah nampak, walaupun keempat skill tersebut belum maksimal dilaksanakan karena keterbatasan tenaga.

Peran sebagai organisator sudah mulai tampak ketika guru mempersiapkan perangkat pembelajaran. Berdasarkan data penelitian perangkat pembelajaran yang dibuat oleh guru sudah membantu pelaksanaan pembelajaran bagi guru dan membantu menciptakan pembelajaran yang menyenangkan pada anak. Peran sebagai monitor tampak dalam memantau anak dalam kegiatan mengamati sampai mengkomunikasikan sehingga membantu kesulitan yang dialami oleh anak, selain itu guru memberikan pemantauan kepada semua anak ketika anak datang, anak bermain sampai anak pulang. Dalam proses pembelajaran guru TK Negeri Pembina telah memberikan fasilitas belajar pada anak sehingga anak terbantu dalam belajarnya, seperti media belajar, alat peraga, mengajak anak untuk keluar sekolah agar pembelajaran lebih kongkrit. Peran yang selanjutnya adalah sebagai evaluator, guru TK Negeri Pembina telah memberikan penilaian terhadap anak walaupun penilaian yang dilakukan belum maksimal karena guru melakukan penilaian berdasarkan apa yang diingat karena dilakukan ketika proses pembelajaran selesai dilaksanakan. Kegiatan penilaian sangat berkaitan dengan pemantauan (monitoring) terhadap perkembangan anak, kurangnya kontrol dalam pemantauan terhadap anak maka penilaian pun juga kurang maksimal, sehingga guru harus melakukan pemantauan secermat mungkin agar mendapatkan penilaian yang autentik (Warsono, 2013).

Selain empat keterampilan di atas guru TK Negeri Pembina juga memiliki keterampilan dalam memotivasi anak dalam belajar yaitu memberikan ucapan pujian kepada anak agar semangat belajarnya meningkat. Pujian juga diberikan guru untuk setiap hasil belajar/hasil karya yang dibuat oleh anak apapun hasilnya. Dengan memberikan ucapan-ucapan positif atau pujian kepada anak dapat merangsang semangat belajar anak. Selain pujian bentuk motivasi lain yang diberikan adalah metode pembelajaran yang bervariasi, metode yang menarik mampu menjadi sarana membangkitkan motivasi belajar anak (Suprihatin, 2015).

\section{Pengembangan Kreativitas Anak Usia Dini dalam Pembelajaran Saintifik di TK Negeri Pembina Kota Salatiga}

Setiap anak memiliki potensi kreatif dan potensi tersebut harus dikembangkan. Anak memiliki jiwa yang unik tidak sama dengan orang dewasa. Karakteristik unik yang dimiliki anak belum tentu dapat berkembang dengan baik apabila dalam mereka tidak diberi kesempatan untuk mengembangkan potensi kreatif. Banyak orang beranggapan bahwa kreativitas hanyalah sekedar bakat dalam bidang seni atau musik saja, pandangan tersebut kurang lengkap. Kreativitas meliputi berbagai bidang diantaranya penemuan ilmiah, imajinasi, eksperimen, eksplorasi, dan penemuan (Musbikin, 2006).

Selain orang tua, pusat pendidikan anak dalam mengembangkan kreativitas adalah lembaga pendidikan, yang memiliki tanggung jawab terhadap perkembangan dan pendidikan anak yaitu peran guru, sehingga guru harus mempunyai kompetensi dalam mempersiapkan objek belajar anak, sumber belajar, media belajar dan mengelola model pembelajaran yang mampu mengembangkan kreativitas anak. Adapun pengembangan kreativitas anak dengan pembelajaran saintifik dapat diuraikan sebagai berikut: 


\section{Mengamati}

Kegiatan pengamatan yang dilakukan TK Negeri Pembina dengan cara anak mengamati berbagai media dan sumber belajar variatif yang disediakan oleh guru, selain itu guru juga mengajak anak untuk bereksplorasi di luar kelas untuk melihat lingkungan disekitar, seperti pengamatan tanaman dan hewan yang berada di sekitar sekolah, outbond, dan juga wisata edukasi. Dengan pengalaman langsung dan media yang menarik anak lebih antusias dan aktif dalam proses pembelajaran. Kegiatan mengamati melatih anak untuk melihat sesuatu dengan teliti, membantu anak dalam mengenal sesuatu yang baru. Mengamati memberikan kesempatan pada anak untuk melihat, memahami, merasakan yang akhirnya dapat membantu anak untuk membuat sesuatu yang menarik.

Proses pembelajaran dengan pengamatan langsung membantu guru dalam mengelola pembelajaran lebih variatif, karena aktivitas anak untuk memegang pensil dan mengerjakan lembar tugas yang menjadi kegiatan monoton sudah mulai berkurang anak lebih banyak dilibatkan dalam pembelajaran yang kongkrit sehingga tercipta pembelajaran yang menyenangkan, anak lebih mudah dalam belajar dan membantu memunculkan ide kreatif anak.

Kegiatan mengamati mampu mambantu berkembangnya proses kreatif yaitu penggunaan indera yang banyak dalam pengamatan menjadikan anak aktif dalam pembelajaran, anak mampu menciptakan ide-ide baru yang lebih variatif seperti menjadikan botol menjadi pesawat, menjadikan balok menjadi kapal, membuat anak bermain seolaholah menjadi pilot, nahkoda, pramugari, pegawai bandara dan lain-lain. Menurut Parnes yang dikutip oleh Yeni Rachmawati, menyebutkan bahwa ciri-ciri pribadi yang kreatif adalah: 1) Fluency, yaitu kemampuan mengemukakan ide untuk memecahkan masalah; 2) Flexibility; yaitu kemampuan menghasilkan berbagai ide; 3) Originality, yaitu kemampuan memberikan respon yang unik dan luar biasa; 4) Elaboration, yaitu kemampuan menyatakan pengarahan ide secara terperinci; 5) Sensitivity, yaitu kepekaan menangkap dan menghasilkan masalah sebagai tanggapan terhadap suatu situasi (Rahmawati \& Euis, 2011:14). Dalam proses pembelajaran guru memberikan apresiasi setiap yang dibuat anak, memberikan komentar positif kepada anak untuk mengembangkan kreativitasnya. Anak yang mendapatkan kesempatan, dorongan, sarana, lingkungan yang mendukung serta cara mendidik yang baik mampu membantu berkembangnya kreativitas anak (Santrock, 2007:58).

\section{Menanya}

Selama masa observasi di TK Negeri Pembina Salatiga peneliti menemukan banyak hal-hal unik dan kreatif yang dilakukan oleh guru, seperti saat menyampaikan dengan metode cerita, dalam bercerita tidak sekedar bercerita tetapi juga mengilustrasikan dengan gambar dan menggunakan beberapa peraga yang membuat anak tertarik untuk mendegarkan. Gambar yang dibuat guru sudah memunculkan pertanyaan dari anak "bu guru menggambar apa ya?" Kegiatan bertanya melatih siswa lebih cermat dalam melihat suatu informasi, sehingga anak mampu merumuskan masalah terkait informasi yang telah diamati. Apa yang menjadi pertanyaan murid guru selalu memberikan tanggapan dengan baik, selain itu guru membantu anak- anak dalam menyusun pertanyaan yang baik agar kemampuan bertanya pada anak terlatih. Ada anak yang bertanya: "bu guru, kok sopir pesawat jet gak jatuh saat jet berguling-guling?" Guru membantu anak yang belum bisa membuat kalimat tanya yang benar dengan mengulangi maksud pertanyaan anak, sehingga membantu anak membuat pertanyaan yang baik dan benar, menjadi “Mengapa pilot tidak jatuh saat beratraksi?" Dari pertanyaan tersebut banyak sekali bermunculan jawaban dari anak, seperti; "karena ada sabuk", "karena jalannya cepat", "karena pintar", "karena latihan" dan lain-lain. Semakin sering anak dilatih bertanya dan diberi pertanyaan, maka anak akan semakin kreatif dalam memunculkan ide dari suatu informasi yang diperoleh. 
Kegiatan pembelajaran dengan sering memberikan kesempatan kepada anak untuk bertanya dan diberi pertanyaan dapat megembangkan rasa percaya diri anak dalam berpendapat dan berbicara. Dengan demikian siswa terlatih memiliki rasa percaya diri yang tinggi sebagai ciri kemampuan anak kreatif. Hal sama diungkapkan Supriadi yang dikutip oleh Yeni Rahmawati bahwa ciri kepribadian kreatif yaitu percaya diri dan mandiri serta senang mengajukan pertanyaan yang baik (Rahmawati \& Euis, 2011:23).

\section{Mengumpulkan informasi}

Anak memperoleh informasi yang bervariasi dengan cara guru memberikan berbagai sumber belajar bagi anak untuk diamati, dipegang, dimainkan, dicoba dan lain-lain. Dalam mengumpulkan informasi anak melihat media atau peraga yang dibawa oleh guru yaitu buku ensiklopedia, mainan, peraga, dan menirukan gerakan dan bunyi yang diperagakan oleh guru. Anak juga diminta memegang buku untuk dibaca, dilihatkan film dari video, serta meminta anak bertanya kepada orang tua tentang tema pembelajaran yang dipelajari ketika di rumah.

Kegiatan mengumpulkan informasi menjadikan anak lebih mandiri dalam menggali informasi, menemukan jawaban atas pertanyaaan dan rasa ingin tahunya sehingga menguasai materi pembelajaran. Kegiatan mengumpulkan informasi juga mampu melatih anak dalam menyelesaikan masalah sehingga memililiki alternatif dalam menyelesaikan permasalahan yang dialami. Mengumpulkan informasi mampu memacu berpikir kritis siswa yang fleksibel yaitu menemukan penyelesaian masalah yang tidak terpaku pada satu cara tetapi beragam cara.

Peran guru sebagai fasilitator memberi kemudahan anak dalam mengumpulkan informasi sehingga mengantarkan anak pada proses kreatif yaitu mampu memberi banyak ide dari berbagai beragam informasi yang diperoleh guna memecahkan suatu masalah dan terbuka terhadap pengalaman baru sebagai ciri anak kreatif. Guru memberikan media pembelajaran dan Sarana belajar yang bervariasi untuk merangsang dan mendorong anak untuk bereksperimen dan bereksplorsi untuk mengembangkan kreativitas anak, hal sama diungkapkan oleh Kenedi dalam penelitiannya, bahwa dalam mengembangkan kreativitas anak diperlukan media pembelajaran yang bervariatif pula (Kenedi, 2017).

\section{Menalar}

Hasil pengamatan peneliti dalam proses pembelajaran dan dari dokumentasi RPPH yang dibuat guru, setiap hari guru membuka empat area dengan empat kegiatan yang berbeda, guru memberi kebebasan kepada anak untuk memilih kegiatan yang disukai anak. Menurut peneliti ketika guru memberikan kebebasan anak dalam memilih kegiatan mana yang disukai terlebih dahulu, akan memberikan gambaran kepada anak untuk membuat suatu keputusan mengenai kegiatan apakah yang akan mereka pilih, bagaimana melakukan, apa yang akan dibuatnya merupakan salah satu pembelajaran mampu mengembangkan berpikir dan menalar pada anak yang mampu mengembangkan kreativitas anak yaitu memecahkan suatu masalah.

Kegiatan menalar lain seperti dalam kegiatan membandingkan kecepatan kendaraan, mengelompokkan jenis kendaraan, melakukan pengukuran besar-kecil dengan botol mampu mengembangkan kemampuan anak dalam berpikir logis dan memberikan jawaban yang tepat terhadap suatu permasalahan. Semakin banyak pengetahuan yang diperoleh anak, dan semakin sering anak diberi keleluasaan untuk mencoba hal baru maka semakin tinggi kreativitas yang muncul pada anak (Munandar, 2009:20).

Dalam menalar guru memberikan suatu permasalahan kepada anak dan meminta anak untuk menyelesaikan masalah tersebut, seperti "kapal layar yang tidak dapat bergerak karena tidak ada angin", guru meminta anak memberikan berbagai solusi dari masalah tersebut. Diskusi merupakan salah satu metode yang dipakai oleh guru TK Pembina dalam menyelesaikan permasalahan, anak diberi kebebasan untuk berpendapat dan 
menyampaikan idenya dan juga kebebasan bertanya. Dalam diskusi tersebut ada beberapa anak memberikan solusi, yaitu dengan memakai mesin, didayung, ditarik kapal besar, menunggu angin datang dan lain-lain. Diskusi menjadikan anak menjadi anak yang berani berbicara dihadapan orang banyak dan membiasakan menjadi anak yang mau mendengarkan oranglain berbicara, sehingga sifat menghargai pendapat orang lain berkembang. Diskusi memberi pengalaman dan latihan anak dalam menghadapi masalah sehingga mengembangkan penalaran, kreativitas dalam memberi pendapat dan berpikir kritis anak (Akromah and Rohmah, 2019).

\section{Mengkomunikasikan}

Dalam kegiatan mengkomunikasikan informasi yang telah diperoleh, guru memberi kebebasan kepada anak untuk mengembangkan kreativitasnya seperti mengelompokkan kendaraarn sesuai dengan jenisnya, menggambar bandara, menggambar kendaraan udara dan laut, membuat pesawat dari botol bekas, membangun bandara dari balok, bercerita tentang pengamalan naik atau melihat kendaraan udara dan laut, menirukan jalan pesawat dan lain-lain. Dalam kegiatan tersebut, anak-anak sangat aktif dan kreatif, ada anak yang mampu mencipatakan kondisi pesawat dalam kelas dengan menyusun kursi untuk penumpang, ada yang berperan menjadi pilot, penjual tiket, pegawai bandara dan lain-lain. Hal itu menunjukkan imaginasi anak berkembang.

Setiap yang dilakukan atau dibuat oleh anak, guru selalu meminta kepada anak untuk menceritakannya. Dari hasil observasi sebagian besar anak-anak mampu menceritakan hasil gambarnya dengan lancar, mampu menggambar dengan kreatif dari hasil informasi yang didapat, mampu membuat hasil karya dari mengamati yang dicontohkan oleh guru maupun yang tidak dicontohkan, serta memainkan mainan dengan penuh imaginasi.

Kegiatan mengkomunikasikan melatih mental dan kemampuan psikomotorik anak dalam berbicara didepan banyak orang. Melalui kegiatan ini siswa dapat terus mengasah kemampuannya mengutarakan ide dengan lancar, berani mengungkapkan pendapat dengan lancar dan jelas serta dengan menggunakan kalimat yang baik dan benar. Dengan menggambar imaginasi, fantasi, dan ide kreatif anak muncul. Dengan bercerita memperkaya kosa-kata, mampu menyusun kalimat sederhana serta rasa percaya diri anak meningkat. Dampak dari pembiasaan mengkomunikasikan adalah sikap jujur, teliti, toleransi, kemampuan berpikir sistematis, mengungkapkan pendapat dengan singkat dan jelas, dan mengembangkan kemampuan berbahasa yang baik dan benar (Kemendikbud, 2013).

Kreativitas tidak bisa diukur dengan alat ukur atau alat hitungan, akan tetapi kreativitas dapat dilihat dari cara anak mengungkapkan ide atau pikirannya, cara memperlakukan benda-benda yang dianggap orang lain tidak berguna, dan ide-ide membuat karya. Kreativitas pada setiap anak dapat dikembangkan melalui proses pembelajaran dan juga rangsangan. Pemberian kesempatan anak untuk beraktivitas melalui kegiatan bermain, eksplorasi, bereksperimen dengan membuat suatu mainan, gambar, coretan dapat memunculkan kreativitas pada anak. Kreativitas anak dapat berkembang dengan baik dengan cara anak diberi kebebasan untuk mengekspresikan diri dan tanpa ada paksaan, peran guru tidak mendominasi dalam pembelajaran (Priyanto, 2015). Dukungan orang tua, lingkungan serta peran guru dalam mempersiapkan objek belajar, memantau setiap aktivitas anak, memberi kemudahan anak dalam belajar sehingga membantu mengembangkan kreativitas anak.

\section{SIMPULAN}

Pembelajaran di TK Negeri Pembina sudah menunjukkan penerapan pembelajaran saintifik, guru masih kesulitan dalam mengontrol dan memberikan penilaian di setiap aktivitas anak dikarenakan rasio guru: murid melebihi rasio ideal. Pembelajaran saintifik melalui 5M mampu mengembangkan kreativitas anak usia dini yaitu, dapat 
mengembangkan ide kreatif dan rasa ingin tahu anak, membantu anak menemukan solusi terhadap masalah, mengembangkan bahasa anak serta sikap percaya diri anak, dan mampu mengembangkan imaginasi dan kreativitas anak.

\section{UCAPAN TERIMAKASIH}

Terimkasih kami ucapkan kepada Kepala Sekolah TK Negeri Pembina Kota Salatiga yang telah memberikan izin dan bantuan kepada penulis untuk melakukan penelitian di sekolah tersebut. Terimakasih kepada guru TK Negeri Pembina yang telah banyak membantu, sehingga dalam pengumpulan data di lapangan dapat berjalan dengan baik sesuai dengan tujuan yang diharapkan. Dan terimakasih kepada reviewer serta editor Jurnal obsesi yang telah membantu memberikan saran, serta masukan dalam perbaikan artikel ini. Semoga kebaikan bapak dan ibu semua tercatat sebagai amal hasanah.

\section{DAFTAR PUSTAKA}

Akromah, J., \& Rohmah, L. (2019). Implementasi Pendekatan Saintifik dalam Mengembangkan Kognitif Anak. Golden Age Jurnal Ilmiah Tumbuh Kembang Anak Usia Dini, 4(1), 47-56. https://doi.org/10.31932/jpaud.v1i2.388

Angkur, M. F. M. (2019). Penerapan Pendekatan Saintifik pada Pendidikan Anak Usia Dini. Jurnal Smart Paud, 2(1), 37. https:// doi.org/10.36709/jspaud.v2i1.5918

Apriyanti, H. (2017). Pemahaman Guru Pendidikan Anak Usia Dini Terhadap Perencanaan Pembelajaran Tematik. Jurnal Obsesi : Jurnal Pendidikan Anak Usia Dini, 1(2), 111. https://doi.org/10.31004/obsesi.v1i2.22

Daryanto. (2015). Pendekatan Pembelajaran Saintifik Kurikulum 2013. yogyakarta: Gava Media.

E.Mulyasa. (2008). Standar Kompetensi dan Sertifikasi Guru. Standar Kompetensi Dan Sertifikasi Guru, 3, 75.

Gardner, H. (2011). Changing Minds: How the Application of the Multiple Intelligences (MI) Framework Could Positively Contribute to the Theory and Practice of International Negotiation. In Psychological and Political Strategies for Peace Negotiation (pp. 1-14). https:// doi.org/10.1007/978-1-4419-7430-3_1

Hariyadi, S. (2014). Bertanya, pemicu kreativitas dalam interaksi belajar. Jurnal Biology Science $\mathcal{E}$ Education, 3(1), 1-16. Retrieved from ejurnal.lp2miainambon.id/index.php/biosel/article/download/196/173\%5Cn

Hosnan, M. (2016). Pendekatan saintifik dan kontekstual dalam pembelajaran abad 21. bogor: penerbit Ghalia Indonesia.

Huberman, M. B. M. dan A. M. (2014). Analisis Data Kualitatif, Buku Sumber Tentang Metode-Metode Baru. In Penerbit Universitas Indonesia (UI-Press). https:// doi.org/Http://uipress.ui.ac.id.

Istiningsih. (2014). Relationship Between Religious Consciousnesses With Scientific Learning (Case Study In Islamic Basic School In Malaysia And Indonesia). IOSR Journal of ResearchEMethod in Education (IOSR-JRME), 4(6).

Kemendikbud. (2013). Peraturan Menteri Pendidikan dan Kebudayaan Republik Indonesia Nomor 81A tahun 2013 tentang Implementasi Kurikulum.

Kemendikbud. (2015). Pedoman Pengelolaan Pembelajaran PAUD. Jakarta: Direktorat Jenderal Pendidikan Anak Usia Dini dan Pendidikan Masyarakat.

Kenedi. (2017). Pengembangan Kreativitas Siswa dalam Proses Pembelajaran di Kelas II SMP Nergeri 3 Rokan IV Koto. Jurnal Ilmu Pendidikan Sosial, Sains, Dan Humaniora, 3(2), 329-348.

Kunandar. (2015). Penilaian Autentik (Penilaian Hasil Belajar Pesrta Didik Berdasarkan Kurikulum 2013. In Jurnal Evaluasi Pendidikan. https:// doi.org/10.21009/JEP.022.05

Machali, I. (1970). Kebijakan Perubahan Kurikulum 2013 dalam Menyongsong Indonesia Emas Tahun 2045. Jurnal Pendidikan Islam, 3(1), 71. 
DOI: 10.31004/obsesi.v5i1.508

https:// doi.org/10.14421/jpi.2014.31.71-94

Maimunah, M. (2016). Metode Penggunaan Media Pembelajaran. Al-Afkar : Jurnal Keislaman E Peradaban, 5(1). https:// doi.org/10.28944/afkar.v5i1.107

Menteri Pendidikan dan Kebudayaan republik Indonesia. (2014). Standar Nasional Pendidikan Anak Usia Dini. Peraturan Menteri Pendidikan Dan Kebudayaan Republik Indonesia, 13.

Munandar, U. (1995). Pengembangan Kreativitas Anak Berbakat. Jakarta: Rineka Cipta.

Mundia Sari, K., \& Setiawan, H. (2020). Kompetensi Pedagogik Guru dalam Melaksanakan Penilaian Pembelajaran Anak Usia Dini. Jurnal Obsesi : Jurnal Pendidikan Anak Usia Dini, 4(2), 900. https:// doi.org/10.31004/obsesi.v4i2.478

Musbikin, I. (2006). Mendidik anak kreatif ala Einstein. Yogyakarta: Mitra Pustaka.

Priyanto, A. (2015). Pengembangan Kreativitas pada Anak Usia Dini melalui Aktivitas Bermain. Jurnal Ilmiah Guru Caraka Olah Pikir Edukatif, (2).

Putri, H. (2017). Konsep Pendidikan Anak Usia Dini dalam Perspektif Islam. Khazanah: Jurnal Studi Islam Dan Humaniora, 13(2), 215. https:/ / doi.org/10.18592/khazanah.v14i2.1634

Rachmawati, Y. (2012). Strategi Pengembangan Kreativitas pada Anak. Jakarta: Prenada Mulia.

Ridwan, A. (2014). Pembelajaran Saintifik untuk Implementasi Kurikulum 2013. (S. Yayat, Ed.). Jakarta: PT Bumi Aksara.

Rusman. (2015). Pembelajaran Tematik Terpadu: Teori, Praktik dan Penilaian. https:// doi.org/10.1016/j.matdes.2019.107759

Santrock, J. W. (2007). Psikologi Perkembangan. (11th ed.). Jakarta: Erlangga.

Suprihatin, S. (2015). Upaya Guru dalam Meningkatkan Motivasi Belajar Siswa. PROMOSI (Jurnal Pendidikan Ekonomi), 3(1). https://doi.org/10.24127/ja.v3i1.144

Uno, H. B. (2009). Profesi Kependidikan Problema, Solusi, dan Reformasi Pendidikan di Indonesia. Jakarta: Bumi Aksara.

Warsono, \& Harianto. (2012). Pembelajaran Aktif Teori Dan Asesmen. Bandung: Rosdakarya.

Yunita, H., Meilanie, S. M., \& Fahrurrozi, F. (2019). Meningkatkan Kemampuan Berpikir Kritis melalui Pendekatan Saintifik. Jurnal Obsesi : Jurnal Pendidikan Anak Usia Dini, 3(2), 425. https://doi.org/10.31004/obsesi.v3i2.228

Yusri, N. (2015). Keterkaitan Scientifik learning dengan kemampuan berfikir kritis (Kajian proses pembelajaran di Sekolah Dasar Budi Mulia Dua Sedayu Bantul). UIN Sunan Kalijaga. 